\title{
Recent Developments in Solar Desalination with Thermal Energy Storage
}

\author{
Bhumit Solanki*, Jatin Patel** \\ *Department of Mechanical Engineering, School of Technology, Pandit Deendayal Petroleum University, \\ Gandhinagar, Gujarat 382007, India \\ **Department of Mechanical Engineering, School of Technology, Pandit Deendayal Petroleum University, \\ Gandhinagar, Gujarat 382007, India \\ Corresponding Author: Bhumit Solanki
}

\begin{abstract}
Solar still is very optimistic option for obtaining fresh water from saline or brackish water as it uses solar energy which is free, non-toxic and inexhaustible. Continuous efforts have been made by various researchers worldwide to increase its productivity. Solar still can be integrated with energy storage materials to improve the distillate output. An energy storage substance stores the energy in the form of sensible heat or latent heat during daytime and releases it during off sunshine hours thus resulting in increase of fresh water output. In the present work, an emphasis has been given to review the configurations and performance of solar still integrated with various thermal storage materials.
\end{abstract}

Keywords: desalination, energy storage materials, PCM, phase change materials, productivity enhancement, solar still.

\section{INTRODUCTION}

Water is essential for existence of human life. The fresh water is required for many domestic and industrial applications. The main sources of fresh water on the earth are lakes, rivers, ponds and underground water which form very less proportion of earth's total water. Further, out of this fresh water, the potable water availability is very less. The major proportion of earth's surface is covered by ocean water which has high proportion of salinity and cannot be directly used. Hence, potable water production and distillation of saline water is necessary which can be done by many conventional and non-conventional techniques. One of the techniques to extract fresh water from the saline water is by using solar distillation because it is easy to manufacture, inexpensive and maintenance free. The solar distillation systems uses solar energy which is renewable source of energy and hence solar distillation is always a pretty option.

Solar systems are of two types: active solar system and passive solar system. In active solar system, some external source of energy is provided in order to enhance the evaporation rate and the productivity of the system. In case of passive solar still, only sunlight is necessary for the operation of solar system which results in lesser evaporation rate and hence low productivity. The output of passive system is less as compared to active solar system.
Solar still is passive type solar system which works on very simple principle of water evaporation and condensation. The saline water is filled in the black basin to absorb the maximum solar radiation. The water temperature increases and starts evaporating. The vapour rises up leaving the impurities and salinity behind it which gets condense on the underside of the glass cover and the vapour condenses to fresh water. The parameters that affect the solar still includes the material of basin, wind speed, depth of water in the basin, solar insolation, inclination angle of glass cover and ambient temperature. The temperature difference between the basin water and inner side of glass cover greatly affects the productivity of the solar still. Higher the temperature difference between the inner side glass cover and water, higher will be the productivity of solar still. The major drawback of solar still is its low productivity and hence it is not used for commercial and industrial applications. The solar still is solar energy dependent and only produces the output during daytime. The output during the off sun shine hours is zero. A method that may be used for improving the productivity of solar stills is by using storage systems. These systems could be sensible or latent heat systems. This method utilizes the heat dissipated from the bottom of the still. The latent heat thermal energy storage systems have many advantages over sensible heat storage systems including a large energy storage capacity per unit 
volume and almost constant temperature for charging and discharging. Various researchers have therefore integrated the solar still with various energy storage materials to enhance the productivity. Fig. 1 to 15 shows the schematics of various possible ways of distillate enhancement by different researchers and their outcomes are listed in Table 1.

Table 1: Work done by various researchers by augmenting solar still with various energy storage materials

\begin{tabular}{|c|c|c|c|c|c|}
\hline $\begin{array}{l}\text { Sr. } \\
\text { No. }\end{array}$ & $\begin{array}{c}\text { Name of the } \\
\text { author }\end{array}$ & $\begin{array}{l}\text { Location and } \\
\text { Year of } \\
\text { Publication }\end{array}$ & $\begin{array}{l}\text { Desalination } \\
\text { Process }\end{array}$ & Augmented by & $\begin{array}{c}\text { Improvement in } \\
\text { efficiency (Distillate) / } \\
\text { Remarks }\end{array}$ \\
\hline 1 & $\begin{array}{c}\text { Arunkumar et al. } \\
{[1]}\end{array}$ & $\begin{array}{l}\text { India } \\
(2013)\end{array}$ & $\begin{array}{l}\text { Hemispherical } \\
\text { basin solar still } \\
\text { with concentrator }\end{array}$ & $\begin{array}{l}\text { Without copper } \\
\text { balls with Paraffin } \\
\text { wax } \\
\text { With copper balls } \\
\text { with Paraffin wax }\end{array}$ & $\begin{array}{c}3.520 \mathrm{~kg} / \mathrm{m}^{2} \text { - day } \\
4.460 \mathrm{~kg} / \mathrm{m}^{2} \text {-day } \\
(26 \%)\end{array}$ \\
\hline 2 & $\begin{array}{c}\text { Sathyamurthy et } \\
\text { al. [2] }\end{array}$ & $\begin{array}{l}\text { Hyderabad, } \\
\text { India } \\
(2014)\end{array}$ & $\begin{array}{c}\text { Triangular pyramid } \\
\text { solar still }\end{array}$ & $\begin{array}{l}\text { Without LHTES } \\
\text { With LHTES }\end{array}$ & $\begin{array}{l}\text { 3.5 L/m }{ }^{2} \text {-day } \\
5.5 \mathrm{~L} / \mathrm{m}^{2} \text {-day }\end{array}$ \\
\hline 3 & $\begin{array}{l}\text { Chaichan and } \\
\text { Kazem [3] }\end{array}$ & $\begin{array}{l}\text { Baghdad, } \\
\text { Iraq } \\
(2015)\end{array}$ & $\begin{array}{l}\text { Conical distiller } \\
\text { integrated with } \\
\text { concentrating dish }\end{array}$ & Paraffin wax & $\begin{array}{c}\text { Increased system } \\
\text { productivity with by } \\
307.54 \%\end{array}$ \\
\hline 4 & $\begin{array}{l}\text { Gugulothu et al. } \\
\text { [4] }\end{array}$ & $\begin{array}{l}\text { Hyderabad, } \\
\text { India } \\
(2015)\end{array}$ & $\begin{array}{l}\text { Single slope solar } \\
\text { still }\end{array}$ & $\begin{array}{c}\text { Potassium } \\
\text { Dichromate } \\
\text { Sodium Sulphate } \\
\text { Sodium Acetate }\end{array}$ & $\begin{array}{c}\text { Sodium Sulphate } \\
\text { provided better yield } \\
\text { compared to Potassium } \\
\text { Dichromate and } \\
\text { Sodium Acetate }\end{array}$ \\
\hline 5 & Kabeel et al. [5] & $\begin{array}{l}\text { Tanta City, } \\
\text { Egypt } \\
(2016)\end{array}$ & $\begin{array}{l}\text { Single slope solar } \\
\text { still }\end{array}$ & $\begin{array}{l}\text { Without Paraffin } \\
\text { Wax } \\
\text { With Paraffin wax } \\
\text { and double pass } \\
\text { solar air collector }\end{array}$ & $\begin{array}{l}4.51 \mathrm{~L} / \mathrm{m}^{2} \text {-day } \\
9.36 \mathrm{~L} / \mathrm{m}^{2} \text {-day }\end{array}$ \\
\hline 6 & $\begin{array}{c}\text { Patel and Kumar } \\
{[6]}\end{array}$ & $\begin{array}{l}\text { Rajkot, } \\
\text { Gujarat } \\
(2016)\end{array}$ & $\begin{array}{l}\text { Single slope single } \\
\text { basin passive solar } \\
\text { still with } 2 \mathrm{~cm} \\
\text { water depth }\end{array}$ & $\begin{array}{l}\text { With Thermic } \\
\quad \text { fluids } \\
\text { With increased } \\
\text { frontal height }\end{array}$ & $\begin{array}{l}11.24 \% \\
23 \%\end{array}$ \\
\hline 7 & Samuel et al. [7] & $\begin{array}{l}\text { Chennai, } \\
\text { India } \\
(2016)\end{array}$ & $\begin{array}{l}\text { Single slope solar } \\
\text { still }\end{array}$ & $\begin{array}{c}\text { Still alone } \\
\text { With spherical ball } \\
\text { heat storage } \\
\text { With sponge }\end{array}$ & $\begin{array}{l}2.4 \mathrm{~kg} / \mathrm{m}^{2} \\
3.7 \mathrm{~kg} / \mathrm{m}^{2} \\
2.6 \mathrm{~kg} / \mathrm{m}^{2}\end{array}$ \\
\hline 8 & Shalaby et al. [8] & $\begin{array}{l}\text { Tanta, Egypt } \\
(2016)\end{array}$ & $\begin{array}{c}\text { V-corrugated } \\
\text { absorber solar still }\end{array}$ & $\begin{array}{l}\text { Without Paraffin } \\
\text { wax } \\
\text { With Paraffin wax } \\
\text { With PCM and } \\
\text { wick }\end{array}$ & $\begin{array}{c}3.36 \mathrm{~kg} / \text { day } \\
12 \% \\
(3.76 \mathrm{~kg} / \text { day }) \\
11.7 \% \\
(3.32 \mathrm{~kg} / \text { day) }\end{array}$ \\
\hline
\end{tabular}




\begin{tabular}{|c|c|c|c|c|c|}
\hline 9 & $\begin{array}{c}\text { Kabeel and } \\
\text { Abdelgaied [9] }\end{array}$ & $\begin{array}{l}\text { Tanta City, } \\
\text { Egypt } \\
(2016)\end{array}$ & $\begin{array}{l}\text { Single slope solar } \\
\text { still }\end{array}$ & $\begin{array}{l}\text { Without Paraffin } \\
\text { Wax } \\
\text { With Paraffin wax }\end{array}$ & $\begin{array}{l}4.51 \mathrm{~L} / \mathrm{m}^{2} \text {-day } \\
7.54 \mathrm{~L} / \mathrm{m}^{2} \text {-day }\end{array}$ \\
\hline 10 & $\begin{array}{c}\text { Mousa and } \\
\text { Gujarathi [10] }\end{array}$ & $\begin{array}{l}\text { Jordan } \\
(2016)\end{array}$ & $\begin{array}{l}\text { Single slope solar } \\
\text { still }\end{array}$ & PCM & $49 \%$ \\
\hline 11 & $\begin{array}{c}\text { Kabeel and } \\
\text { Abdelgaied [11] }\end{array}$ & $\begin{array}{c}\text { Tanta City, } \\
\text { Egypt } \\
\text { (2017) }\end{array}$ & $\begin{array}{l}\text { Single slope solar } \\
\text { still }\end{array}$ & $\begin{array}{l}\text { Without Paraffin } \\
\text { wax } \\
\text { With Paraffin wax } \\
\text { and oil heat } \\
\text { exchanger using } \\
\text { cylindrical } \\
\text { parabolic } \\
\text { concentrator }\end{array}$ & $4.48 \mathrm{~L} / \mathrm{m}^{2}$-day \\
\hline 12 & $\begin{array}{c}\text { Sharshir et al. } \\
\text { [12] }\end{array}$ & $\begin{array}{l}\text { Wuhan, } \\
\text { China } \\
\text { (2017) }\end{array}$ & $\begin{array}{l}\text { Single slope solar } \\
\text { still }\end{array}$ & $\begin{array}{l}\text { With Paraffin wax } \\
\text { and flake graphite } \\
\text { nanoparticles } \\
\text { With Paraffin wax } \\
\text { and flake graphite } \\
\text { nanoparticles and } \\
\text { film cooling }\end{array}$ & $\begin{array}{r}65 \% \\
73.80 \%\end{array}$ \\
\hline 13 & $\begin{array}{c}\text { Faegh and Shafii } \\
{[13]}\end{array}$ & $\begin{array}{l}\text { Tehran } \\
(2017)\end{array}$ & $\begin{array}{l}\text { Single slope solar } \\
\text { still }\end{array}$ & $\begin{array}{l}\text { Without PCM and } \\
\text { with external } \\
\text { condenser } \\
\text { With PCM and } \\
\text { with external } \\
\text { condenser }\end{array}$ & $\begin{array}{c}56 \% \\
\\
86 \% \\
\left(6.555 \mathrm{~kg} / \mathrm{m}^{2} \text {-day }\right)\end{array}$ \\
\hline 14 & $\begin{array}{l}\text { Deshmukh and } \\
\text { Thombre [14] }\end{array}$ & $\begin{array}{c}\text { Maharashtra, } \\
\text { India } \\
(2017)\end{array}$ & $\begin{array}{c}\text { Single slope single } \\
\text { basin solar still }\end{array}$ & $\begin{array}{c}\text { Still alone } \\
\text { With servotherm } \\
\text { medium oil } \\
\text { With sand }\end{array}$ & $\begin{array}{l}4.734 \mathrm{~kg} / \mathrm{m}^{2} \\
4.778 \mathrm{~kg} / \mathrm{m}^{2} \\
4.566 \mathrm{~kg} / \mathrm{m}^{2}\end{array}$ \\
\hline 15 & $\begin{array}{l}\text { Arunkumar and } \\
\text { Kabeel [15] }\end{array}$ & $\begin{array}{c}\text { Coimbatore- } \\
\text { India } \\
(2017)\end{array}$ & $\begin{array}{l}\text { Compound } \\
\text { parabolic } \\
\text { concentrator } \\
\text { (CPC)-concentric } \\
\text { circular tubular } \\
\text { solar still }\end{array}$ & $\begin{array}{l}\text { Without Paraffin } \\
\quad \text { wax } \\
\text { With Paraffin wax }\end{array}$ & $\begin{array}{c}5.330 \mathrm{~L} / \mathrm{m}^{2} \text {-day } \\
5.779 \mathrm{~L} / \mathrm{m}^{2} \text {-day } \\
(8 \%)\end{array}$ \\
\hline
\end{tabular}

\section{CONCLUSION}

The various researchers as discussed above have used various thermal energy storage materials like dyes, oils, sand and phase change materials to enhance the productivity. The energy storage materials were also accompanied by various techniques such as film cooling, external condenser and double pass air collector to further improve the efficiency of solar still. On the basis of available open literature, the following conclusions can be inferred:

- It is found that the effect of mass of PCM plays an important role in designing the solar still. 
- After sunset, the PCM acts as a heat source for the basin water to maintain the temperature difference with the glass cover. The effectiveness of PCM becomes more compelling at lower masses of the basin water during low sunshine hours.

- The hourly distillate output of the solar still with and without the PCM depends strongly on the basin water glass cover temperature difference.

- It is observed that overnight productivity increases with increase in storage and water mass while daylight productivity, in general, decreases with the increase in storage and water mass.

- Integration of concentrating collectors with solar still shows considerable enhancement of distillate output.

The further work can be carried out by using nano fluids along with the external condenser, PCM and concentrating collectors to maximize the fresh water output.

\section{REFERENCES}

[1] Arunkumar, T., Denkenberger, D., Ahsan A. and Jayaprakash, R., The augmentation of distillate yield by using concentrator coupled solar still with phase change material, Desalination, 314, 2013, 189-192.

[2] Sathyamurthy, R., Nagarajan, P.K., Subramani, J., Vijayakumar, D. and Ali, K.M.A., Effect of water mass on triangular pyramid solar still using phase change material as storage medium, Energy Procedia, 61, 2014, 2224-2228.

[3] Chaichan, M.T. and Kazem, H.A., Water solar distiller productivity enhancement using concentrating solar water heater and phase change material (PCM), Case Studies in Thermal Engineering, 5, 2015, 151-159.

[4] Gugulothu, R., Somanchi, N.S., Vilasagarapu, D. and Banoth, H.B., Solar Water Distillation Using Three Different Phase Change Materials, Materials Today: Proceedings, 2(4-5), 2015, 1868-1875.

[5] Kabeel, A.E., Abdelgaied, M. and Mahgoub, M., The performance of a modified solar still using hot air injection and PCM, Desalination, 379, 2016, 102107.

[6] Patel, P. and Kumar, R., Comparative Performance Evaluation of Modified
Passive Solar Still Using Sensible Heat Storage Material and Increased Frontal Height, Procedia Technology, 23, 2016, 431-438.

[7] Samuel, D.H., Nagarajan, P.K., Sathyamurthy, R., El-Agouz, S.A. and Kannan, E., Improving the yield of fresh water in conventional solar still using low cost energy storage material, Energy Conversion and Management, 112, 2016, 125-134.

[8] Shalaby, S.M., El-Bialy, E. and El-Sebaii, A.A., An experimental investigation of a vcorrugated absorber single-basin solar still using PCM, Desalination, 398, 2016, 247255.

[9] Kabeel, A.E. and Abdelgaied, M., Improving the performance of solar still by using PCM as a thermal storage medium under Egyptian conditions, Desalination, 383, 2016, 22-28.

[10] Mousa, H. and Gujarathi, A.M., Modeling and analysis the productivity of solar desalination units with phase change materials, Renewable Energy, 95, 2016, 225-232.

[11] Kabeel, A.E. and Abdelgaied, M., Observational study of modified solar still coupled with oil serpentine loop from cylindrical parabolic concentrator and phase changing material under basin, Solar Energy, 144, 2017, 71-78.

[12] Sharshir, S.W., Peng, G., Wu, L., Essa, F.A., Kabeel, A.E. and Yang, N., The effects of flake graphite nanoparticles, phase change material, and film cooling on the solar still performance, Applied Energy, 191, 2017, 358-366.

[13] Faegh, M. and Shafii, M.B., Experimental investigation of a solar still equipped with an external heat storage system using phase change materials and heat pipes, Desalination, 409, 2017, 128-135.

[14] Deshmukh, H.S. and Thombre, S.B., Solar distillation with single basin solar still using sensible heat storage materials, Desalination, 410, 2017, 91-98.

[15] Arunkumar, T. and Kabeel, A.E., Effect of phase change material on concentric circular tubular solar still-Integration meets enhancement, Desalination, 414, 2017, 4650. 


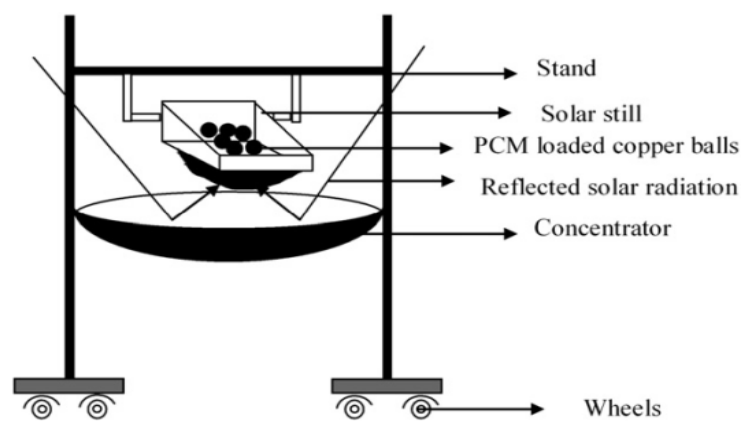

Fig. 1. Schematic view of a solar concentrator coupled hemispherical basin single slope solar still [1]

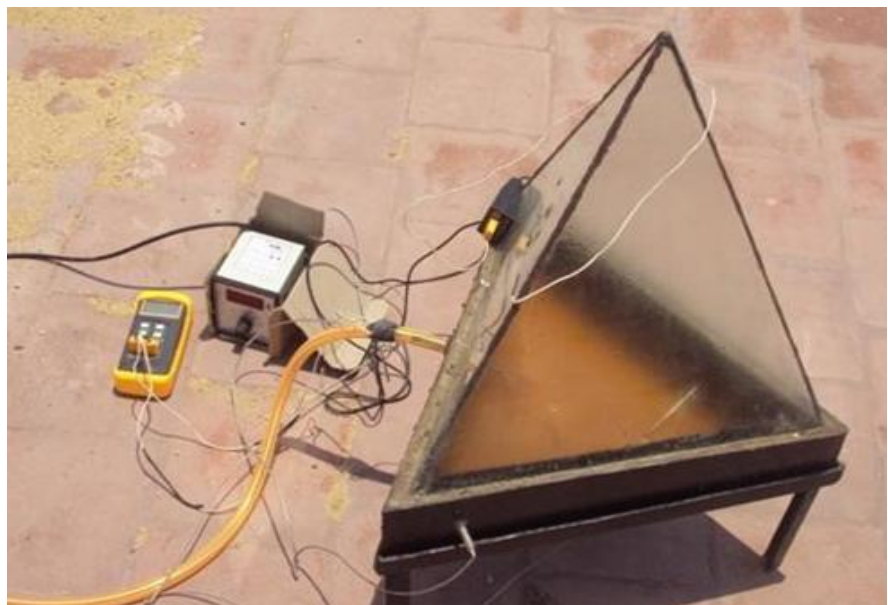

Fig. 2. Pyramid type solar distiller [2]

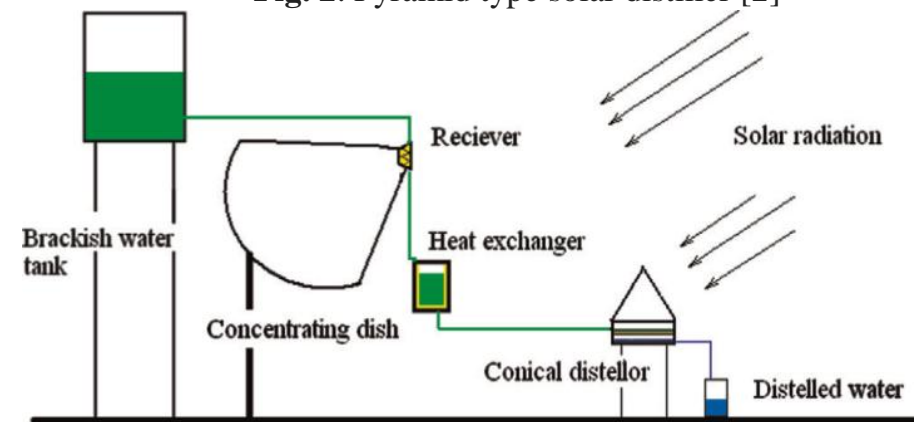

Fig. 3. A schematic diagram solar distiller integrated with concentrating dish [3]

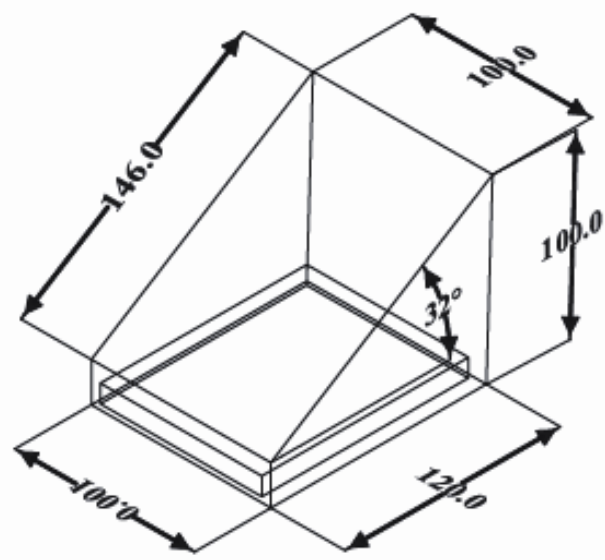

Fig. 4. Single slope solar still with thermal storage material in basin [4] 


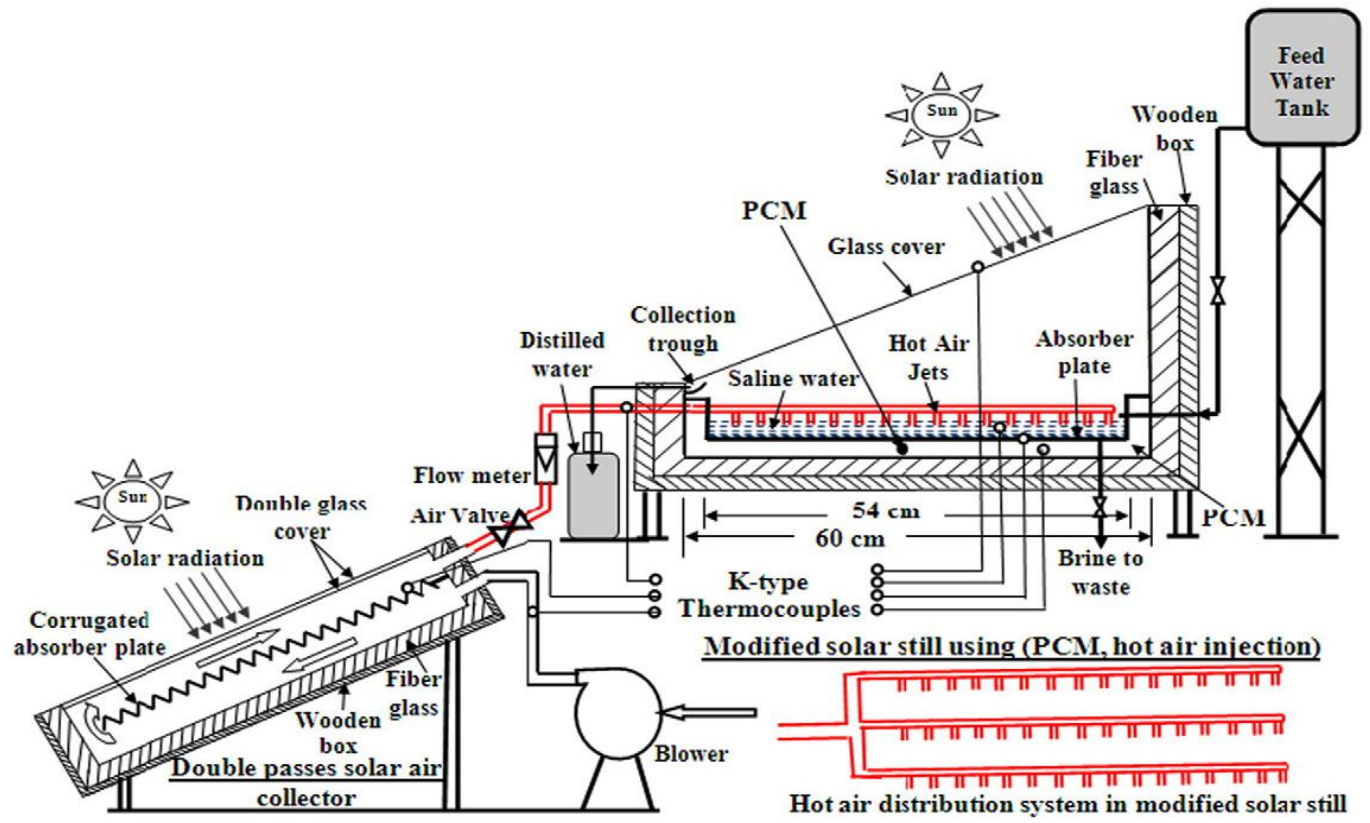

Fig. 5. Schematic diagram of the double passes solar air collector integrated modified solar still with PCM [5]

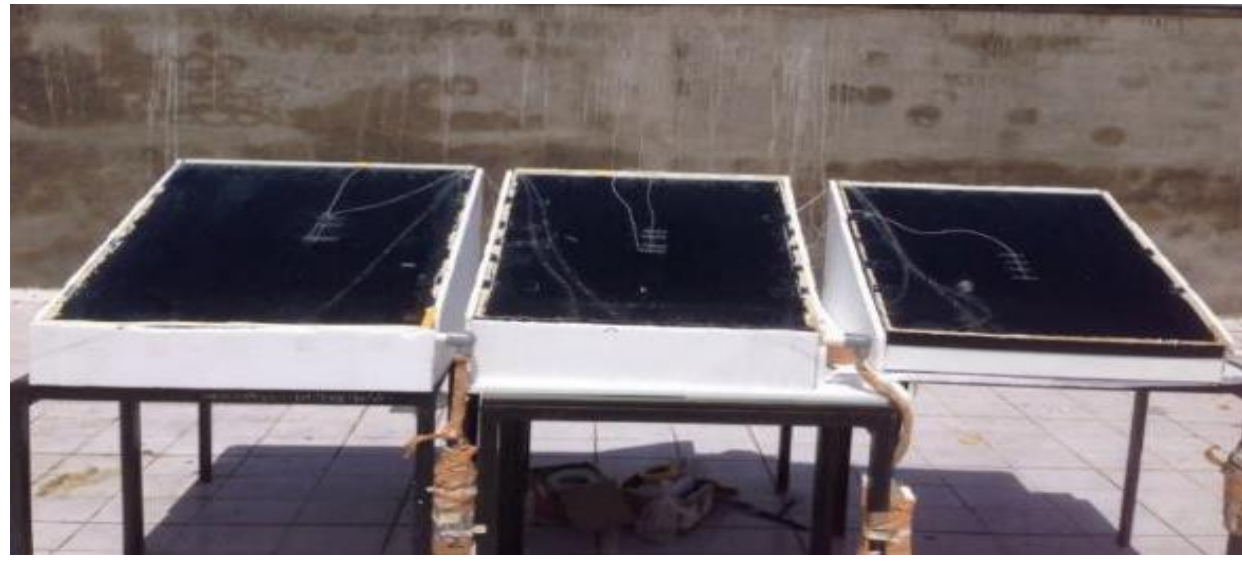

Fig. 6. Modified Passive Solar Still Using Sensible Heat Storage [6]
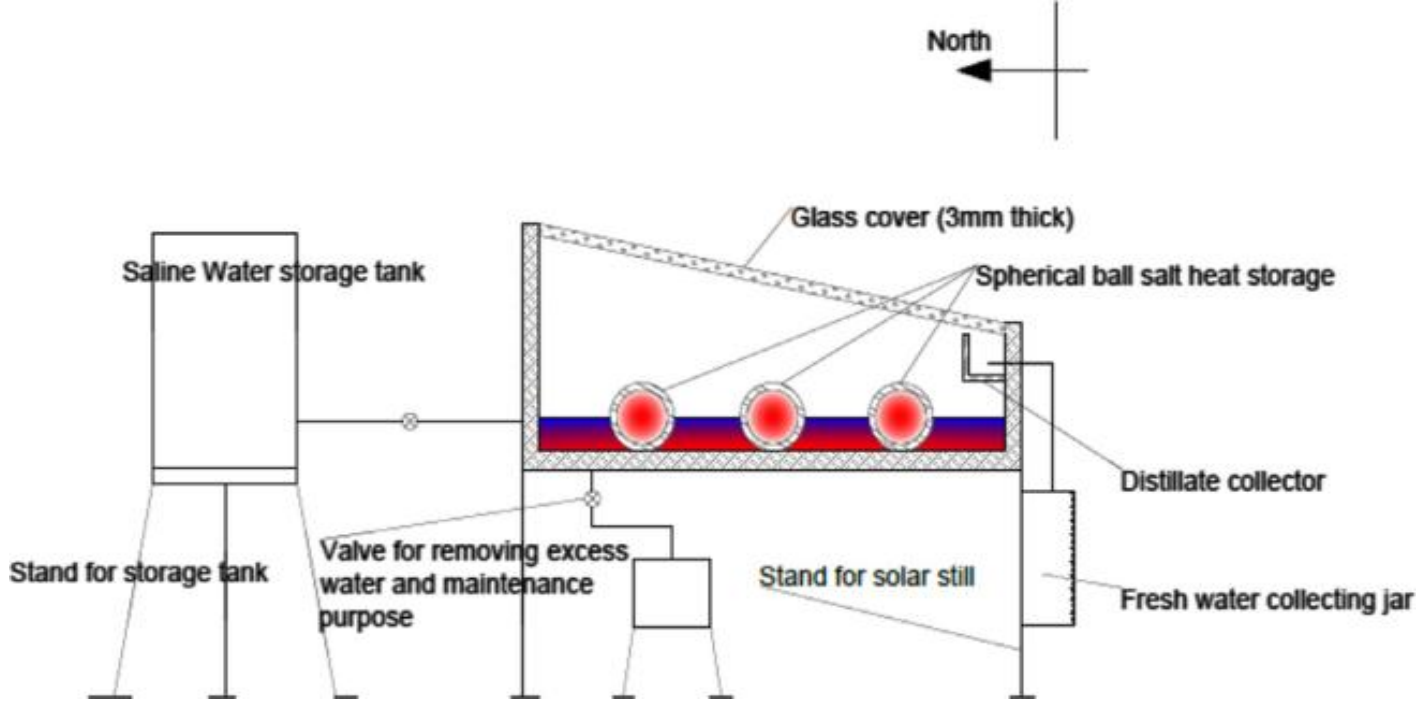

Fig. 7. Schematic diagram of a conventional solar still with encapsulated spherical ball salt heat storage [7] 


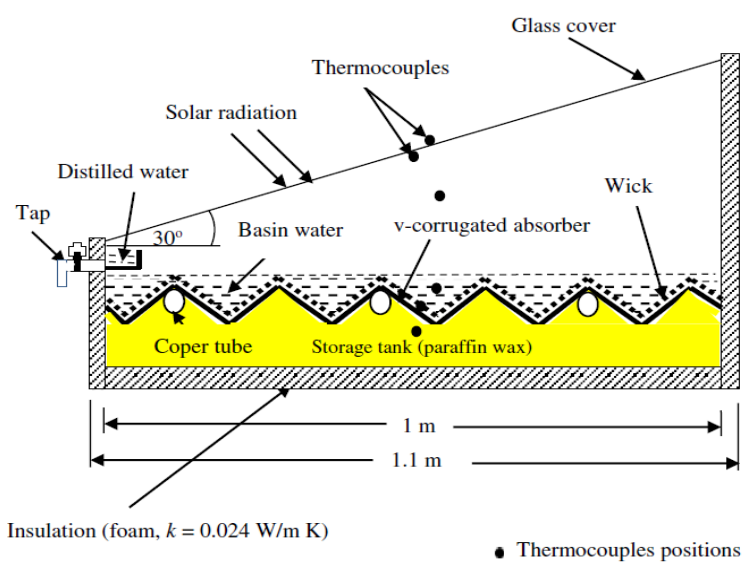

Fig. 8. Single slope single basin solar still with corrugated absorber plate (VSBSS) with PCM as a thermal heat storage medium [8]

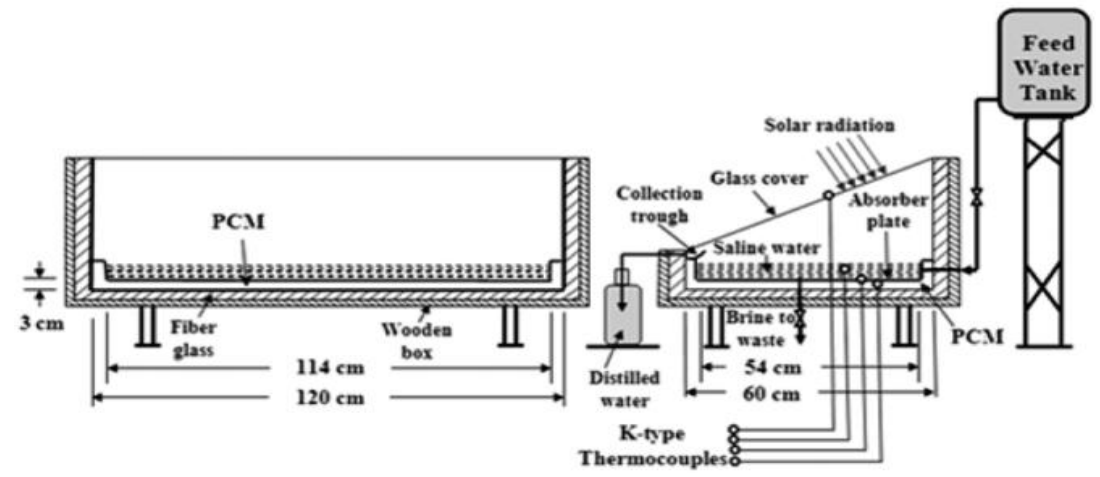

Fig. 9. Schematic diagram of the experimental setup of Solar Still with Phase Change Material [9]

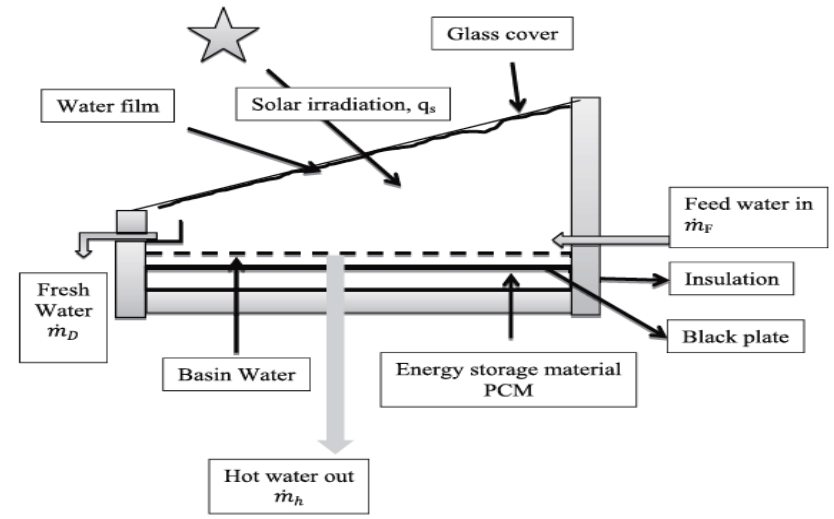

Fig. 10. Schematic of desalination unit with PCM [10]

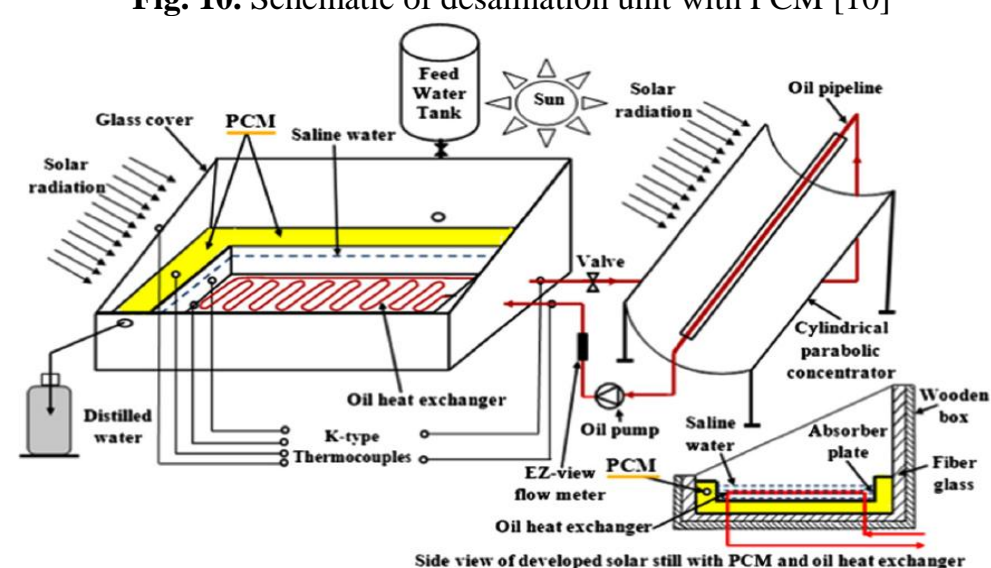


Fig. 11. Schematic diagram of slar still with (oil heat exchanger, PCM)-coupled with a cylindrical parabolic concentrator [11]

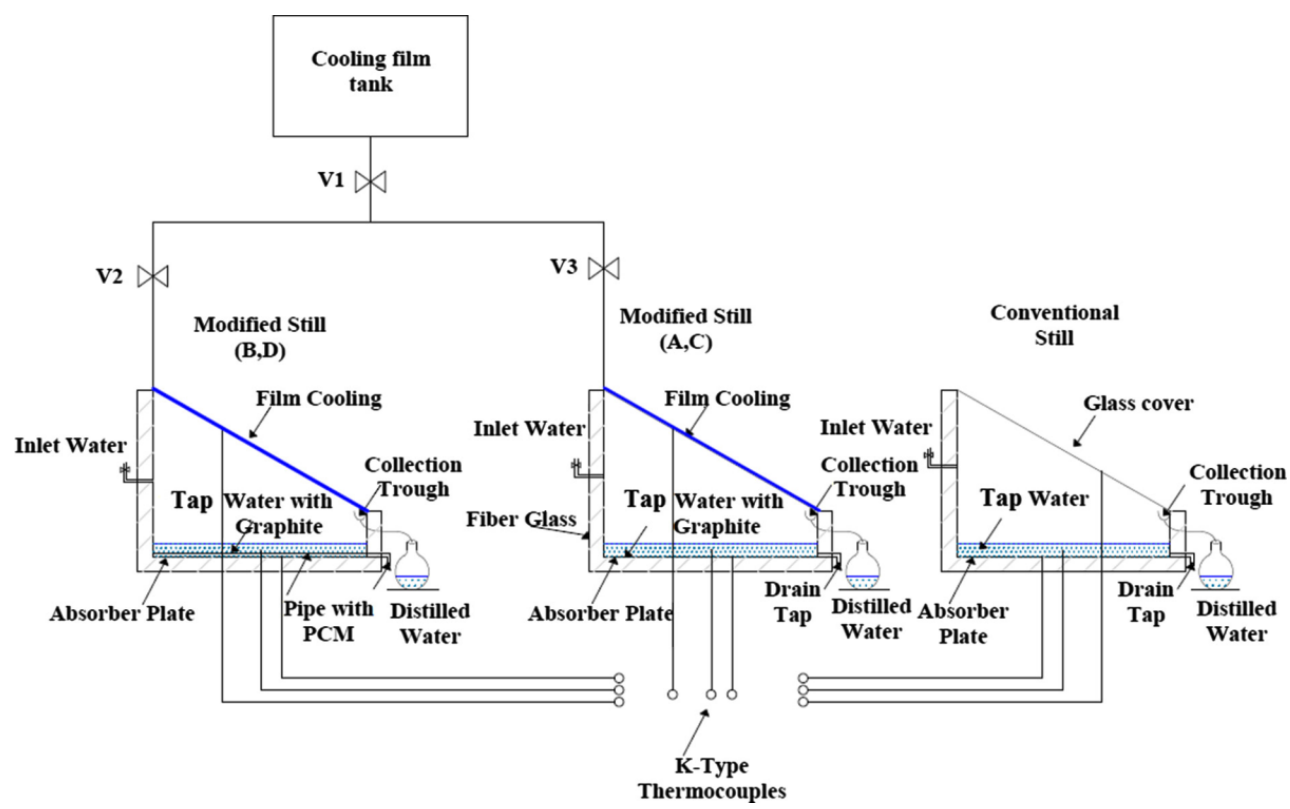

Fig. 12. Schematic sketch of experimental setup to study the effects of flake graphite nano-particles, phase change material, and film cooling on the solar still performance [12]

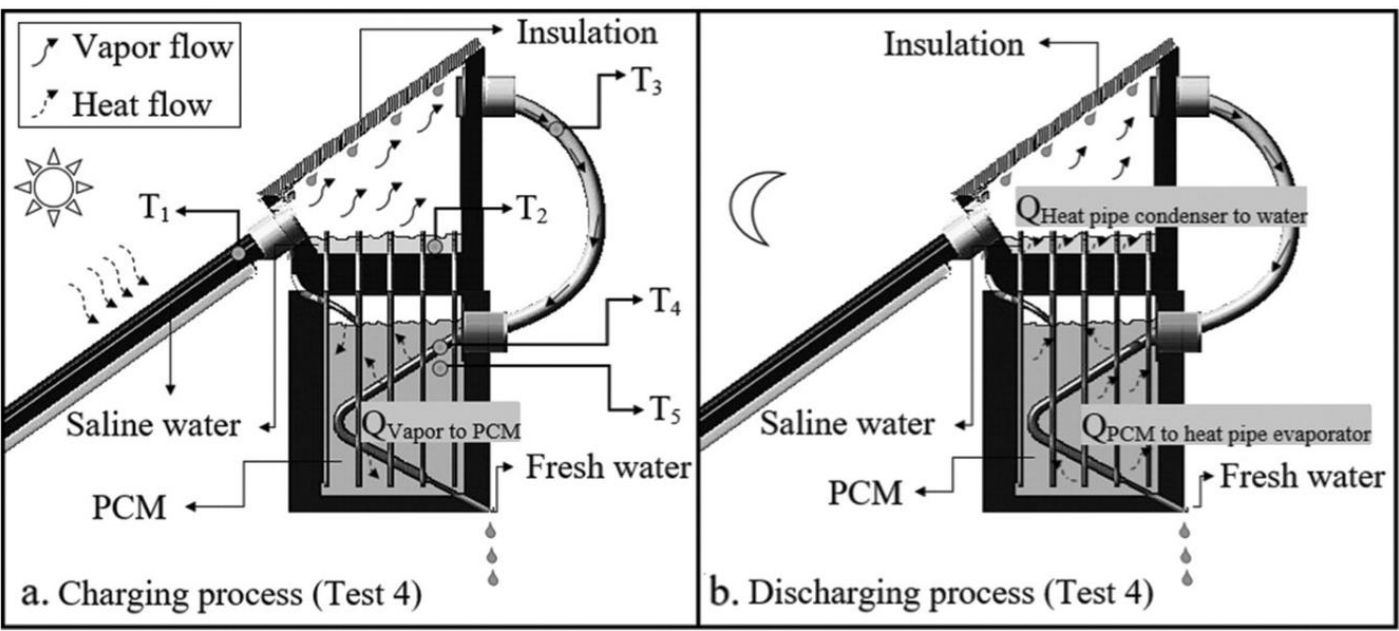

Fig. 13. Schematic of the processes in the system with external condenser containing PCM and heat pipes (a) charging process (b) discharging process [13]

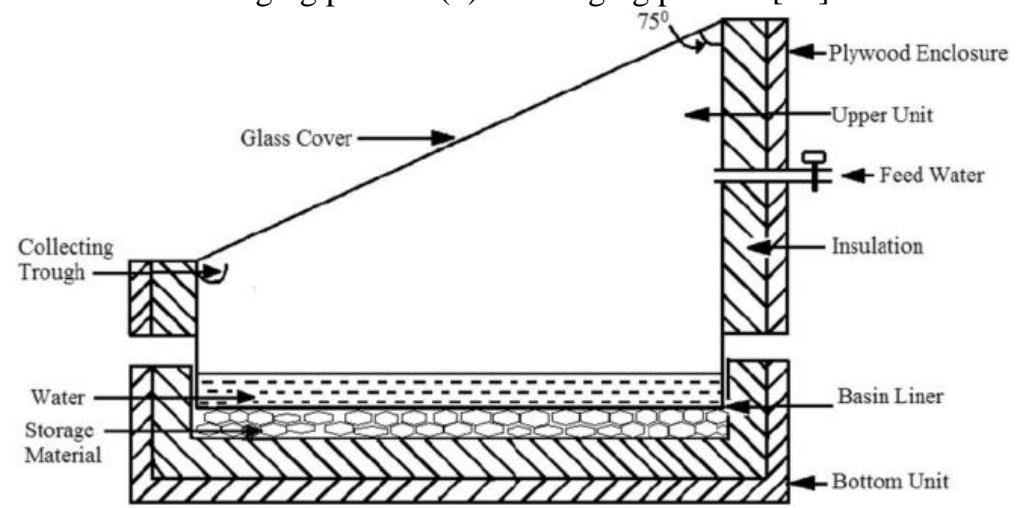

Fig. 14. Schematic of solar still with single basin solar still using sensible heat storage materials [14] 


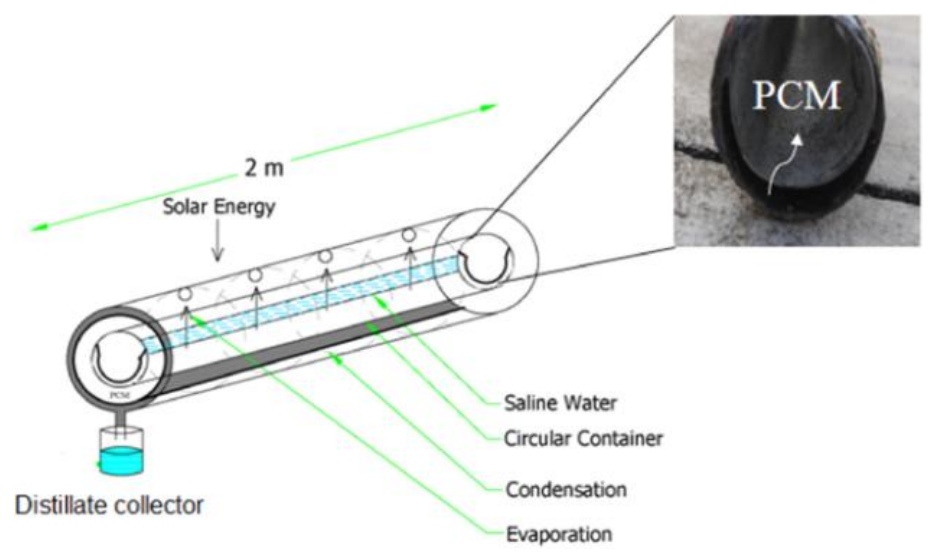

Fig. 15. View of concentric circular tubular solar still-Integration with PCM portion [15] 80.82), NASA, Ads, Researcher Id Thomson Reuters, DOAJ.

Bhumit Solanki. "Recent Developments in Solar Desalination with Thermal Energy Storage." International Journal of Engineering Research and Applications (IJERA) 7.7 (2017): 28-36. 